\title{
Incorporating Private Savings Behavior in Product Offerings: A Case Study of Pakistan
}

\author{
Salman Ahmed Shaikh \\ Project Director and Editor, Islamic Economics Project \\ E-mail: salman@siswa.ukm.edu.my
}

JEL Classification:

G11

G21

G23

Received: December 15, 2020

Revised: January 19, 2021

Accepted: February 25, 2021

\begin{abstract}
In order to enhance understanding about the actual savings behaviour and impulses which drive savings behaviour, it is interesting to study the micro foundations of savings behaviour. Collecting micro data through filled questionnaire from households in urban areas, this study identifies the motives of savings and the instruments and channels where the savings are invested in Pakistan. The results reveal that investment motive, higher income and greater frequency of household members joining labor force for earning incomes enhance the monthly savings rate. The results can be used to offer Islamic investment deposits in an attractive way. If the investment deposits are pitched properly by highlighting the stable ex-post investment returns and low ex-post volatility, then people with an investment motive parking their savings in fixed income mutual funds would be attracted towards Islamic investment deposits. Likewise, incremental long-term savings plans wherein periodic investments increase over a period of time can be offered given that monthly savings rate are found to be positively associated with income. Finally, joint investment accounts can be offered given the finding that monthly savings rate is higher in households with greater number of earning members in family.
\end{abstract}

\section{Keywords:}

savings, Consumption, Savings Motives, Investment Motive.

How to Cite:

Shaikh, S. A. (2021). Incorporating Private Savings Behavior in Product Offerings: A Case Study of Pakistan. Signifikan: Jurnal Ilmu Ekonomi, 10(2), 247-258. https://doi.org/10.15408/sjie.v10i2.20139. 


\section{Introduction}

Among the regional neighbours and comparable developing countries globally, Pakistan has one of the lowest rates of savings. It is well known from the growth literature that lower savings lead to lower level of investment and capital formation (Solow, 1956). As per the classical growth theories, lower levels of capital formation result in lower rates of economic growth. Therefore, in order to enhance rate of investment and capital formation, it is vital to boost savings (Ahmad \& Asghar, 2004). Empirical evidence from the regional countries seems to justify this line of reasoning. The rate of economic growth is higher in Southeast Asia since they are able to have higher rates of investment financed by higher rates of private savings. The comparativly lower rate of economic growth in Pakistan seems to coincide with the relatively lower rate of private savings in the country as compared to the South East Asian region.

For effective policymaking, there is need for evidence based policies. This requires a careful understanding of private savings behaviour. A complication arises in analysis of savings in developing countries because of the lack of true representation of economic behaviour in the aggregate data. Macroeconomic data in Pakistan is collected in such a way that aggregate consumption series is measured as a residual. It also does not have any detail of the division of total consumption between durable and non-durable consumption. The frequency of reported statistics on aggregate consumption is also annual which does not allow meaningful and robust analysis. Thus, in order to enhance understanding about the actual savings behaviour and impulses which drive savings behaviour, it is interesting to study the microfoundations of savings behaviuour.

Table 1 reveals that bank account penetration in Pakistan is even lower than the average for low income countries. On the other hand, due to relatively more developed financial markets as compared to low income countries, Pakistan's domestic credit by the finance sector as a percent of GDP is slightly better than the average for low income countries. Nonetheless, domestic credit by banks as a percent of GDP is also lower in Pakistan as compared to even the average for low income countries.

Table 1. Comparative Picture of Financial Inclusion in Pakistan

\begin{tabular}{lccc}
\hline Country Group & $\begin{array}{c}\text { Bank Accounts } \\
\text { (\% of Adult } \\
\text { Population) }\end{array}$ & $\begin{array}{c}\text { Domestic Credit by } \\
\text { Finance Sector } \\
\text { (\% GDP) }\end{array}$ & $\begin{array}{c}\text { Domestic Credit by } \\
\text { Banks } \\
\text { (\% GDP) }\end{array}$ \\
\hline Pakistan & 21.29 & 58.28 & 18.89 \\
Low income & 34.85 & 25.91 & 20.40 \\
Middle income & 65.31 & 148.80 & 101.60 \\
High income & 93.71 & 188.44 & 79.20 \\
\hline
\end{tabular}

Source: World Development Indicators, World Bank 2018

Since private savings constitute as much as $90 \%$ of total savings due to large fiscal deficits, it is pertinent to analyze the private savings behavior in Pakistan at the micro 
level. There is a need to investigate the rates of savings across households to determine the impact of demographic characteristics. Furthermore, it is important to explore the motive and forms of savings and how they are utilized (Azhar, 1995).

Lower savings may be caused due to lower per capita incomes, high inflation, lower returns on savings, lack of profitable options for investing the saved funds and lower proportion of working age population joining the labour force, for instance. In this backdrop, this study attempts to understand the savings behavior at the micro level and to get an understanding of the preferences of the people regarding risk, maturity and motives for savings. The results can help in identifying the actual avenues people use to park their savings. Finally, the study will assist in identifying the motives behind savings and the asset class choices for different savings motives.

In theories of consumption, Absolute Income Hypothesis (AIH) is a pioneer work to explain consumption behavior. AIH suggests that the average propensity to consume (APC) falls as income rises (Keynes, 1936). The natural implication of this conjecture is that rich people would relatively save more of the increase in their incomes. Early cross sectional and long time series studies supported this conjecture (Williams \& Zimmerman, 1935; Stigler, 1954). But, post-World War II period presented an empirical challenge to this theory. Despite the rise in incomes, the APC did not fall (Kuznets et al., 1946). To reconcile theory with empirical evidence, Lifecycle Consumption Hypothesis (Modigliani \& Brumberg, 1954) and Permanent Income Hypothesis (Friedman, 1957) posit that people desire to have smooth consumption throughout their lifetimes. Both theories provide the theoretical foundation for this phenomenon in a rational choice framework in a dynamic setting.

In empirical studies for Pakistan using micro level data, some studies find an interesting case that rural areas may have high rates of savings as compared to urban areas (Abid \& Afridi, 2010). Empirical evidence from rural areas indicate that despite having lower levels of incomes and budget, the propensity to save among rural households is higher than the overall national average (Azhar, 1995). Using Household Income and Expenditure Survey data, Burney \& Khan (1992) also conclude that the propensity to save among rural households is higher than that of urban households.

The reasons could be the motive of precautionary and buffer stock savings in the face of higher liquidity constraints in rural areas as compared to urban areas (Azhar, 1995). People migrating from rural areas to urban areas or to abroad for work send remittances back home. These remittances might be regarded as transitory income by the remaining members of the household in the home country. Thus, if permanent income hypothesis is evoked to explain this finding, the remittances are regarded as transitory income by the recipients in the home country and hence mostly saved.

Another possible reason could be higher conspicuous consumption in urban areas. If relative income hypothesis by Duesenberry (1949) is used to describe the results, people tend to consume in a way others do in their network and social circle. Ali (1985) using Household Income and Expenditure Survey data estimates Extended Linear Expenditure 
System (ELES). Spending on rent on housing, furniture, education, recreation, and travelling were found to be income-elastic. The consumption of such items is more prevalent in urban areas as compared to rural areas. Iqbal and Jamal (1992) do a further deeper analysis by comparing behaviour in rural and urban households. They find that as per the marginal budget shares, the prominent heads of spending are Food and Rent in rural areas while Food, Rent and Transport dominate in urban areas.

Two other possible reasons for higher propensity to save among rural households include lower food inflation in rural areas and greater volatility in incomes in rural areas. Lower food inflation allows rural households to have a lower spending on essential food intake, especially if they are producing food by themselves. Secondly, volatility in incomes in the face of lesser options to approach financial institution for liquidity constraints compel rural households to have increased precautionary savings as a buffer stock (Deaton, 1990).

Furthermore, Rehman et al. (2011) finds that urban households save less due to high cost of children's educational expenditures to be paid by household head and who is typically the prime saver in the family. This is also confirmed by Burney \& Khan (1992) in their empirical study. Nonetheless, Burney \& Khan (1992) using Household Income and Expenditure Survey find that with increase in age, savings tend to increase and towards the tail end of life, the change in the rate of savings becomes negative. Even the recent research literature in post-financial development era confirms this finding (Basit et al., 2010). Thus, this empirical evidence is in conformity with the basic proposition of lifecycle hypothesis.

On the other hand, the rate of private savings in Pakistan is lower as compared to other Asian countries. In the context of lifecycle hypothesis, the aggregate private savings will be higher if the ratio of working age population to total population ratio is higher as suggested by Husain (1996). The higher dependency ratio and lower ratio of working age population in overall population mix tends to depress savings (Ahmad \& Asghar, 2004). Furthermore, the composition of household also plays a role in determining savings. It is found that large families tend to save less (Abid \& Afridi, 2010). Larger families may have greater number of dependents. Thus, spending on a larger family leaves a household with lesser amount of savings. Other studies also confirm the significance of age dependency ratio in reducing savings (Farhan, 2011).

Another interesting finding by Ahmad \& Asghar (2004) using micro data reveals that households who own house tend to save less. This evidence is also confirmed by Aziz \& Ashfaq (2009) who find that real estate ownership decreases savings. This might be because of two reasons. If house is financed through a financial institution, mortgage installments take away part of income which reduces savings. Furthermore, households who own house have enough safety to liquidate their fixed asset and overcome any spending shortfall or gain spendable resources through liquidation of asset at a higher premium price. Thus, their need for precautionary saving and buffer stock saving would be insignificant. 
Other empirical studies conclude that participation of spouse, dependency ratio, household income and size of real estate boost household savings (Rehman et al, 2010). Conversely, marital status, size of family, debts, educational expenditure and value of a house significantly reduce savings level of households. It might be because married household head in a big-size family where there are children undergoing education tend to have lower room for savings. Also, debts and their repayment might leave little surplus for savings. Finally, increase in the value of a house tends to function as increase in lifetime resources for funding higher future consumption and it tends to reduce the need for liquid savings if the future consumption is not to be increased in the short run.

\section{Methods}

This study collects primary data from 300 people through a structured questionnaire from urban households. Both descriptive and inferential tools are employed. Contingency tables are used to highlight possible relationships between different factors in the study.

For regression analysis, multiple regression analysis is used. For estimating the coefficients, Newey and West (1987) robust standard errors are used. Finally, Ramsey (1969) RESET test and Tukey link test is used to check model specification.

\section{Results and Discussion}

This section presents descriptive and inferential analysis. Table 2 gives profile of respondents by occupation.

Table 2. Occupational Profile of Survey Participants

\begin{tabular}{lcc}
\hline \multicolumn{1}{c}{ Form of Occupation } & Number of Participants & Proportion in Survey \\
\hline Academic - Salaried & 58 & $19.60 \%$ \\
Non Academic - Salaried & 174 & $58.80 \%$ \\
Freelancer / Self Employed & 43 & $14.5 \%$ \\
Businessperson & 21 & $7.1 \%$ \\
\hline
\end{tabular}

Table 3 gives descriptive statistics for demographic variables. An interesting finding is that the ratio of earning members in family to total members in family is estimated to be $37 \%$. The survey respondents largely include people belonging to upper middle class or upper class. It shows that low labor force participation is not necessarily a rural phenomenon. Since the average monthly income of survey respondents exceeds Rs 100,000 , this lower ratio of earning members in family can also not be attributed to lower income. This evidence is consistent with the evidence accumulated by Banerjee \& Duflo (2011). Norms, culture and habits play an important role too in seemingly pure economic decisions. 
Table 3. Demographic Characteristics of Survey Participants

\begin{tabular}{lcccc}
\hline Demographic Characteristics & Average & Standard Deviation & Lowest Value & Highest Value \\
\hline Age & 31.63 & 9.7 & 18 & 85 \\
Household Size & 5.53 & 2.35 & 1 & 18 \\
Earning Members in Family & 2.06 & 1.02 & 1 & 7 \\
Dependent Members & 3.46 & 2.02 & 0 & 13 \\
\hline
\end{tabular}

In the dependency statistics, it is found that most households have non-earning family members. As many as $67 \%$ of the households state that two or more members in the family do not earn any income. Only in $5 \%$ of the households, it is found that there was no non-earning member in the family. Furthermore, less than 5\% of the household surveyed had no non-earning family members. This demographic trend is consistent with high prevalence of joint family system in Pakistan.

Using the cross sectional data, the simple linear regression of monthly savings on monthly income yields estimated value of marginal propensity to save of 0.34 . Since the average income of the households that were surveyed in this study was higher than Rs 100,000, the higher estimated value of marginal propensity to save is understandable. Theory and empirical evidence also supports the view that households with higher disposable income and wealth tend to save more than the poorer households (Jappelli \& Pistaferri, 2014; Keynes, 1936; Lusardi, 1996; Marugasu et al., 2013; Souleles, 1995).

Next, the motives for savings are discussed. Table 4 reports the distribution of responses. It is revealed that almost two-thirds of the survey respondents save due to the precautionary motive. This indicates the existence of liquidity constraints which hinder intertemporal consumption smoothing. Investment motive is less potent reason to save. This might be because of high inflation, lower rates on saving instruments and higher volatility in rates of return.

Table 4. Motives of Savings among Survey Participants

\begin{tabular}{cc}
\hline Motive of Savings & Number of Survey Participants \\
\hline Precautionary Savings & 150 \\
Investment Motive & 89 \\
Family Requirements & 163 \\
Business Requirements & 27 \\
\hline
\end{tabular}

It is also interesting to explore the forms in which savings are utilized. The survey participants were asked to rank their preference to invest their savings in 8 different instruments or asset classes. The scoring is done based on the rank assigned by each respondent. If an instrument is given a rank 1 by a respondent, a score of 8 is awarded 
to that instrument and if an instrument is given a rank 8 , a score of 1 is awarded to that instrument and so on. The instruments in the order of the highest to the lowest ranked are: Equity funds, money market funds, real estate, national savings scheme, gold, bonds, stocks and bank deposits.

Table 5. Preference for Savings with Investment Motive with Mean Score

\begin{tabular}{lccccccccc}
\hline \multicolumn{1}{c}{ Rank/Asset Class } & $\mathbf{1}$ & $\mathbf{2}$ & $\mathbf{3}$ & $\mathbf{4}$ & $\mathbf{5}$ & $\mathbf{6}$ & $\mathbf{7}$ & $\mathbf{8}$ & Score \\
\hline Stocks & 37 & 35 & 49 & 49 & 33 & 21 & 17 & 21 & 959 \\
Bonds & 3 & 28 & 33 & 49 & 52 & 41 & 36 & 20 & 1,029 \\
National Saving Scheme & 28 & 22 & 44 & 37 & 42 & 36 & 30 & 23 & 1,237 \\
Money Market Funds & 7 & 8 & 19 & 33 & 56 & 65 & 58 & 16 & 1,345 \\
Equity Funds & 9 & 13 & 11 & 21 & 44 & 49 & 57 & 58 & 1,406 \\
Real Estate & 75 & 53 & 38 & 20 & 13 & 28 & 16 & 19 & 1,305 \\
Gold & 75 & 67 & 29 & 26 & 9 & 7 & 37 & 12 & 1,219 \\
Deposits & 28 & 36 & 39 & 27 & 13 & 15 & 11 & 93 & 932 \\
\hline
\end{tabular}

The lower preference for stocks and bank deposits could be due to high volatility in returns in the case of stock investments and lower returns in the case of bank deposits. The higher preference towards mutual funds could be due to tax advantage as well as delegated investment management provided by fund managers to invest funds meticulously and carefully in a volatile market. In fixed income instruments, national saving schemes are preferred over bonds and both are together preferred over bank deposits. This is consistent with the fact that returns on national saving scheme instruments had been higher and they also carry a tax advantage with withholding tax exemption. Bonds are less liquid in the capital market of Pakistan as well as riskier as compared to national saving scheme instruments which are issued by the government. At least on domestic liabilities, government has zero default risk as it has authority to issue new local currency to fund its deficit requirements, albeit with high risk of rise in inflation. Lastly, bank deposits offer stable, but lower returns which are largely not able to overcome the rate of inflation in the economy of Pakistan. Hence, they are preferred less as a mode of investing the saved funds.

To estimate determinants of monthly savings rate, the following econometric model given in equation (1) is estimated empirically.

$$
\text { srate }=\beta_{0}+i m++\beta_{2} p m+\beta_{3} e m f+\beta_{4} \text { Inincome }+\mu
$$

Where:

$\begin{array}{ll}\text { srate } & =\text { Monthly savings rate. } \\ \text { im } & =\text { Investment motive, a dummy variable. } \\ \text { pm } & =\text { Precautionary motive, a dummy variable. }\end{array}$


emf = Total earning members in family.

Inincome $=$ Log of monthly income.

$\beta_{0}, \beta_{1}, \beta_{2}, \beta_{3}$ and $\beta_{4}$ are the parameters of the model.

$\mu \quad=$ Random error term.

Table 6 reports the results using robust standard errors. The coefficients are in line with theory. It is found that if the investment motive is present, it increases the monthly savings rate. Precautionary motive may tend to increase the level of savings for meeting autonomous consumption in future. Since autonomous consumption is constant over time, increase in savings for that motive does not affect the overall savings rate. Thus, expectedly, the slope coefficient for precautionary motive is statistically insignificant. On the other hand, it is discovered that increase in earning members in the family raises the savings rate. This is very much valid for many emerging countries. Increased labor force participation and higher ratio of working age population to total population ratio tends to be associated with higher savings rate.

Table 6. Results of Multiple Regression Analysis

\begin{tabular}{cc}
\hline Variables & Dependent Variable: Monthly Savings Rate \\
\hline Investment Motive & $0.116^{* * *}$ \\
Precautionary Motive & $(5.098)$ \\
Earning Members in Family & 0.0131 \\
& $(0.742)$ \\
Log of Income & $0.0260^{* *}$ \\
& $(2.468)$ \\
Constant & $0.0535^{* * *}$ \\
& $(5.453)$ \\
R-squared & $-0.512^{* * *}$ \\
& $(-4.770)$ \\
\end{tabular}

Finally, the increase in income tends to increase the savings rate. Liquidity constraints are very much significant and binding in a developing economy like Pakistan where the multidimensional poverty level is as much as 38\% in 2016 (Source: United Nations Development Program, 2016) and where less than 20\% and 5\% people have access to bank accounts and formal credit services from banks respectively. Thus, relaxation in budget constraints through increase in income leads to boost the monthly savings rate. Looking at it from another perspective, higher income leads to decline in relative risk aversion. 
Thus, it leads to increase in monthly savings rate. Furthermore, the model diagnostics reveal that the model is overall significant. Ramsey RESET test for model specification and the Tukey link test show that the model is correctly specified.

The results indicate that savings rate is positively associated with investment motive. Therefore, if the deposit products are marketed as forms of investments with clear communication about historical profit rates, then the customers would be willing to switch their current accounts from conventional and Islamic banks to savings accounts. Islamic banks also need to communicate ex-post low volatility in their return on investment deposit schemes. Some people have this apprehension that since Islamic deposits do not guarantee the returns, they might be having high volatility in returns. Nonetheless, with lower non-performing loans to financing ratio in Islamic banking, Islamic banks are able to achieve low ex-post volatility in returns. Thus, in situations where the capital markets face severe bearish pressure as is now the case after the outbreak of COVID-19, Islamic investment deposits offer opportunity to have stable returns with low ex-post volatility. Thus, emphasizing on stable ex-post returns and low ex-post volatility, Islamic banks can mobilize deposits in profit sharing investment accounts (PSIA) from current accountholders in conventional and Islamic banks and fixed income mutual fund investors who invest in cash fund, income fund and money market fund.

Secondly, the results indicate that as income increases, savings rate also increases. Since increase in income is found to be associated with higher monthly savings rate, Islamic banks can also offer flexible and dynamic investment products which enable the investors to increase their savings as their income increases. This could be achieved by advising the investor to deposit increasingly higher investment amounts in later years of life in long term savings plans. Incentives can be offered such as giving higher weightage to larger investment deposits as is also done by some Islamic banks today for their large depositors.

Thirdly, the results indicate that as earning members in family increase, it enhances the monthly savings rate. Such results point towards an opportunity to offer joint investment accounts for family members. The investors will benefit by being able to get preferential weightage on higher investment deposits when the savings are clubbed in single account. Furthermore, an incentive can be given that the cumulative investments by family members in single account will help them avail greater amount of financing. For instance, if $50 \%$ income of spouse is allowed to be clubbed in normal circumstances to avail financing, the percentage will be relaxed to $75 \%$ if they keep a joint investment account with the Islamic banks. It will also help in avoiding smaller and dormant accounts which are costly to administer.

\section{Conclusion}

This study attempted to analyze the micro foundations of savings behavior in urban households in Pakistan. Inferential results highlight that investment motive, a greater number of earning members in family and higher income leads to increase in 
monthly savings rate. It is found that as compared to precautionary motive, savings rate is positively influenced by the presence of investment motive. The results showing statistically significant relationship between income and savings rate highlight the significance of liquidity constraints in developing economies like Pakistan with lower rates of financial inclusion and higher incidence of poverty. In order to boost the savings rate, the government needs to provide incentive for savings for the investment motive by decreasing the withholding tax rate on financial investments by individuals. Furthermore, it is also vital to provide easy access to formal financial services for the masses. Thus, commercial banks shall be incentivized and urged to provide basic banking accounts, small savings accounts and financing products for consumer durables to ease the liquidity constraints. The results also highlight opportunities for Islamic banks to pitch their investment deposits in an attractive way by emphasizing stable ex-post returns and low ex-post volatility and by offering incremental long-term savings plans and joint investment accounts.

\section{References}

Abid, S., \& Afridi, G. S. (2010). Assessing the Household Saving Pattern of Urban and Rural Households in District Muzaffarabad. Pakistan Journal of Life and Social Sciences, 8(2), 137 - 141 .

Ahmad, M., \& Asghar, T. (2004). Estimation of Saving Behaviour in Pakistan Using Micro Data. The Lahore Journal of Economics, 9(2), 73 - 92.

Ali, M. S. (1985). Household Consumption and Saving Behaviour in Pakistan: An Application of the Extended Linear Expenditure System. Pakistan Development Review, 24(1), 23-32.

Azhar, B. A. (1995). Rural Savings: Their Magnitude, Determinants, and Mobilisation. The Pakistan Development Review, 34(4), 779 - 788.

Aziz, B., \& Ashfaq, M. (2009). Socio-Economic Characteristics and Household Saving Behaviour in Pakistan. Journal of Social Sciences and Humanities, 7(1), $45-60$.

Banerjee, A. V., \& Duflo, E. (2011). Poor Economics: A Radical Rethinking of the Way to Fight Global Poverty. New York: Public Affairs.

Basit, A. B., Bashir, F., \& Farooq, F. (2010). How Do Savings Differ among Various Earner Groups in Pakistan? Empirical Evidence from Multan District. Pakistan Journal of Social Sciences, 30(2), 219 - 233.

Burney, N. A., \& Khan, A. H. (1992). Socio-economic Characteristics and Household Savings: An Analysis of the Households' Saving Behaviour in Pakistan. The Pakistan Development Review, 31(1), 31-48.

Deaton, A. (1990). Savings in Developing Countries. Proceedings of the World Bank Annual Conference on Development Economics.

Duesenberry, J. S. (1949). Income, Saving and the Theory of Consumer Behaviour. Cambridge: Harvard University Press.

Farhan, M., \& Akram, M. (2011). Does Income Level Affect Saving Behaviour in 
Pakistan? An ARDL approach to Co-integration for Empirical Assessment. Far East Journal of Psychology and Business, 3(3), 62 - 72.

Friedman, M. (1957). A Theory of the Consumption Function. New Jersey: Princeton University Press.

Husain, A. M. (1996). Private Saving and Its Determinants: The Case of Pakistan. The Pakistan Development Review, 35(1), 49 - 70.

Iqbal, R., \& Jamal, H. (1992). Regional Differences in Consumption Behaviour in Pakistan. Pakistan Economic and Social Review, 30(2), 95 - 108.

Jappelli, T., \& Pistaferri, L. (2014). Fiscal Policy and MPC Heterogeneity. American Economic Journal: Macroeconomics, 6(4), 107 - 136.

Keynes, J. M. (1936). The General Theory of Employment, Interest, and Money. New York: Harcourt Brace \& World.

Kuznets, S., Epstein, L., \& Jenks, E. (1946). Front Matter to National Product Since 1869. In National Product Since 1869. National Bureau of Economic Research.

Lusardi, A. (1996). Permanent Income, Current Income, and Consumption: Evidence from Two Panel Data Sets. Journal of Business \& Economic Statistics, 14(1), 81 - 90.

Modigliani, F. \& Richard, H. B. (1954). Utility Analysis \& the Consumption Function: An Interpretation of Cross-section Data. in Kenneth K. Kurihara (Eds)., Post Keynesian Economics. New Brunswick, NJ: Rutgers University Press, 388 - 436.

Murugasu, D., Wei Ang J. \& Hwa, T. B. (2013). Marginal Propensity to Consume Across Household Income Groups. Bank Negara Malaysia, Working Paper No. WP2/2013.

Newey, W. K., \& West, K. D. (1987). Hypothesis Testing with Efficient Method of Moments Estimation. International Economic Review, 28(3), 777 - 787.

Ramsey, J. B. (1969). Tests for Specification Errors in Classical Linear Least Squares Regression Analysis. Journal of the Royal Statistical Society, 31(2), 350 - 371.

Rehman, H., Bashir, F., \& Faridi, M. Z. (2010). Saving Behavior among Different Income Groups in Pakistan: A Micro Study. International Journal of Humanities and Social Science, 1(10), 17 - 29.

Rehman, H., Chaudhry, I. S., Faridi, M. Z., Bashir, F. (2011). Rural-Urban Saving Differentials in Pakistan: Investigation from Primary Data. South Asian Studies, 26(1), $19-35$.

Solow, R. M. (1956). A Contribution to the Theory of Economic Growth. Quarterly Journal of Economics, 70(1), 65 - 94.

Souleles, N. S. (1999). The Response of Household Consumption to Income Tax Refunds. American Economic Review, 89(4), 947 - 958.

Stigler, G. J. (1954). The Early History of Empirical Studies of Consumer Behaviour. The Journal of Political Economy, 62(2), 95 - 113.

United National Development Programme. (2016). Multi-Dimensional Poverty in Pakistan. UNDP Pakistan. 
Williams, F. M., \& Zimmerman, C. C. (1935). Studies of Family Living in the United States and Other Countries: An Analysis of Material and Method (No. 223). US Department of Agriculture. 